\title{
PERLINDUNGAN HUKUM TERHADAP KORBAN KEKERASANDALAM RUMAH TANGGA (KDRT) DI WILAYAH HUKUM POLRES PIDIE
}

\author{
Suhaibah \\ Program Studi Ilmu Hukum Fakultas Hukum \\ Universitas Jabal Ghafur
}

\begin{abstract}
Domestic Violence or domestic violence (KDRT), in principle is one of the phenomenon of human rights violations so that this issue is covered as one form of discrimination, especially against women. Discrimination itself has been formulated in various legal instruments in Indonesia such as Law Number 7 of 1984 which is a form of ratification of the Convention on the Elimination of All Forms of Discrimination against women formulated by the United Nations (UN), and more recently is Law No. 23 Tahuo 2004 on Domestic Abolition (KDRT), but there is still no significant impact for women victims of discrimination. In fact, there are still very few who understand the content, let alone apply this law from law enforcers alone. Domestic violence can be triggered by many factors, including economic factors, low education, jealousy and can also result in the presence of one person old from both sides, who take part in a household. From education factor can be caused by lack of knowledge from both side how to balance and overcoming unsuitable traits between them, maybe in a household there is husband who have arrogant nature and tend to win by themselves because of lack of knowledge. Legal basis of handling violence in the household, among others, is article 294 paragraph (I) of the Penal Code (KUHP) that threatens a person who commits an obscene act with his or her immature son, stepchild or retrieve, his or her pets and so on with criminal penalty for seven years. Article 340 of the Criminal Code on premeditated murder, Articles 341 and 342 on the murder of women against their babies, Article 356 on family persecution and so on. In addition to the Criminal Code (Penal Code), there are also laws regulating the Elimination of Domestic Violence.
\end{abstract}

Keywords: Domestic Violence

\section{PENDAHULUAN}

Tindak kekerasan yang mengandung faktor jenis kelamin dikenal dengan istilah Gender Violence, dan merupakan persoalan yang jamak dan dapat terjadi di ragam masyarakat mana saja di seluruh belahan dunia. Gender Violence menimpa nyaris seluruh ruang dalam kehidupan perempuan, mulai dari rumah, tempat kerja, tempat umum danjalanan. Meskipun wujud ragam kekerasan tersebut bervariasi daribudaya ke budaya lainnya, namun ada suatu benang merah yang muncul yangmengatasi batasan suku/ras, agama maupun kelas sosial ekonomi, yaitu bahwaperempuan rentan terhadap tindak kekerasan karena jenis kelaminnya sebagaiperempuan .

Kekerasan terhadap perempuan telah menjadi kecemasan bagi setiap Negara di dunia, tennasuk Negara-negara maju yang dikatakan sangat menghargai dan peduli tentang Hak Asasi Manusia (HAM). Sebuah penelitian yang dilakukan di lnggris dan Amerika Utara menyimpulkan bahwa kekerasan domestik terjadi pada setiap satu dari empat keluarga, clan bahwa satu dari sepuluh perempuan mengalamikekerasan dari pasangan hidupnya.

Indonesia sebagai sebuah Negara yang sedang berkembangjuga menyandang predikat buruk karena karena pelanggaran terhadap hak-bak asasi manusia, yangsalah satu diantaranya hak-hak perempuan. Tindak kekerasan terhadap perempuansecara umurn merupakan suatu masalah serius yang dialami oleh banyak perempuandi Indonesia, karena maslah ini ibarat sebuah piramid yang kecil pada puncaknya tapi besar pada bagian desarnya, sebab sulit mendapatkan angka yang pasti karena "pekanya" permasalahan tersebut.

Domestic Violence atau kekerasan dalam rumah tangga (KDRT), padaprinsipnya merupakan salah satu fenomena pelanggaran Hak Asasi Manusia (HAM) sehingga masalah ini tercakup sebagai salah satu bentuk diskriminasi, khususnya terbadap perempuan. Diskriminasi sendiri telah dirumuskan 
dalam berbagai instrument hukum di Indonesia seperti Undang-Undang Nomor 7 Tahun 1984 yang merupakan bentuk ratifikasi Konvensi Penghapusan Segala Bentuk Diskriminasi terhadap perempuan yang dirumuskan oleh Perserikatan Bangsa-Bangsa (PBB), dan yang lebih mutakhir adalah Undang-Undang Nomor 23 Tahuo 2004 tentang Penghapusan Dalam Rumah Tangga (KDRT), namun masih belum ada dampak berartibagi peluang perempuan korban diskriminasi. Pada kenyataannya, masih sangat sedikit yang yang memahami isi, apalagi menerapkan undang-undang ini dari kalangan penegak hukum sendiri.

Kekerasan dalam keluarga atau arena domestic bisa terjadi diantara anggotakeluarga Kekerasan tersebut bisa dilakukan oleh seorang suami kepada istrinya atausebaliknya, seorang ayah atau ibu kepada anak perempuannya, seorang saudara perempuan atau laki-laki kepada saudara perempuan atau laki-laki kepada saudara perempuan/laki-laki Iainnya,dan seterusnya,penyebabnya beragam.

Fakta tentang kekerasan dalam rumah tangga berdasarkan observasi yangdilakukan penulis di Kabupaten Pidie sebagai salah satu kabupaten yang berada di Kabupaten Propinsi Aceh, merupakan Kabupaten yang beragam dalam hal kepercayaan, etnis, pendidikan dan mata pencaharian, menunjukkan bahwa pada masyarakat yang tingkat perekonomiannya rendah, erat kaitannya dengan lingkungantempat tinggal yang kumuh sangat besar pengaruhnya terhadap kehidupan sehari-hariyang mudah timbul ledakan-ledakan emosional yang tak terkendali hingga budaya Kekerasan diyakini mendominasi realita kehidupan sehari-hari, hingga kekuatanfisik/jasmani, kekuatan kelompok merupakan status symbol dan status sosial dalam masyarakat tersebut dan hal mana terdampak pula terbadap pandangan, anggapan serta sikap dalarn mengartikan kehadiran kaum perempuan dalarn lingkungan tersebut, sehingga budaya kekerasan identik dengan masyarakat yang tingkat perekonomiannya rendah. Kenyataan ini juga di dukung dengan masih banyaknya perempuan tidakk mampu menolak perlakuan, sikap anggapan diskriminatifterhadap perempuan.Kekerasan terhadap perempuan dalam rumah tangga bisa disebabkan olehketergantungan ekonomi istri kepada suaminya, karena istri miungkin akan direndahkan oleh suaminya.
Salah satu faktor yang menyebabkan seseorang suamimelakukan tindak kekerasan terhadap istrinya adalah ketidak mandirian si istrisecara ekonomi .

Kemandirian ekonomi yang. dirniliki oleh seorang perempuan akanmeningkatkan harga dirinya dan menyebabkan memiliki posisi tawar yang tinggidalam hubungan dengan suaminya . Berdasarkan teori ini dapat disimpulkan bahwa istri-istri yang memiliki kemandirian ekonomi lebih mungkin berpeluang terbebas dari tindak kekerasan dalam rumah tangga. Apakah halini herlaku juga bagi masyarakat Pidie yang beragam dan bercirikan pola hubungan paternalistic.

Mengenai kekerasan yang terjadi dalam rumah tangga (Domestic Violence) yang terindifikasi di Kabupaten Pidie bahwa korban kekerasan dalam rumah tangga bukan saja dialami oleh perempuan tetapi juga oleh laki-laki ( seperti kekerasan emosional dan ekonomi ), namun mayoritas korban masib dinominasi oleh perempuan, seperti kekerasan fisik yang dilakukan suami terhadap istri dan istri kepada suami.

Berdasarkan masalah diatas, maka permasalahan yang akan diteliti adalah sebagai berikut :

1. Bagaimanakah perlindungan hukum terhadap korban kekerasan dalam rumah tangga?

2. Hambatan yang di hadapi oleh penyidik Polres Pidie dalam penanganan tindak kekerasan dalam rumah tangga ?

3. Apa sajakah upaya pemerintah dalam melindungi korban kekerasan dalamrumah tangga?

\section{LANDASAN TEORITIS TENTANG KEKERASAN DALAM RUMAH TANGGA MENURUT PERATURANUNDANG- UNDANG \\ A. Pengertian Kekerasan Dalam Rumab Tangga}

Perkataan "kekerasan dalam rurnah tangga" terdiri dari satu kata yaitu kekerasan dan rumah tangga. Masing-masiog kata tersebut memiliki pengertian yang jelas tentang apa yang dimaksud dengan kekerasan dalam rumah tangga itu.Kekerasan adalah perbuatan seseorang atau kelompok yang menyebabkan cederaatau matinya orang lain atau menyebabkan kerusakan fisik atau barang 
orang lain. Sedangkan rumah tangga dapat diartikan sebagai yang berkenan dengan urusan kehidupan di rumah, berkenan dengan keluarga. Di samping pengertian umum tentang kekerasan dalam rumah tangga sebagai mana di.kemukakan diatas, ada pengertian resmi tentang kekerasan dalam rumah tangga yang dikemukakan di dalam Undang-Undang Nomor 23 tahun 2004 tentang Pengbapusan kekerasan dalam rumah tangga Di dalam Pasal I angka (I) Undang- Undang Nomor 23 tahuh 2004 dikemukakan bahwa yang dimaksud dengankekerasan dalam rumah tangga adalah :"Setiap perbuatan terhadap seseorang terutama perempuan, yang berakibat timbulnya kesengsaraan dan penderitaan secara fisik, seksual, psikologis, dan/atau penelantaran rumah tangga termas $\mu \mathrm{k}$ ancaman untuk melakukan perbuatan, pemaksaan, atau perampasan kemerdekaan secara melawan secara hukum dalamlingkup rumah tangga".

Undang-Undang No 23 tahun 2004 tentang Penghapusan Kekerasan Dalam Rumah Tangga (PKDRT) lebih memfokuskan kekerasan dalam rumah tangga itu kepada perempuan sebagai korban. -Kekerasan dan penderitaan yang dialami dalam kehidupan sebuab keluarga merupakan bagian yang tidak terpisahkan dan tindak kejahatan. Pada sisi lain kekerasan juga disebut dengan nama tindak pidana atau perbuatan pidana.Kejabatan atau tindak pidana adalah "Suatu perbuatan yang pelakunyadikenakan hukum pidana'". Sedangkan menurul Simons sebagairnana di.kutip oleh Kansil, kejahatan atau tindak pidana adalah"Perbuatan manusia yang bertentangandengan hukum", Perbuatan mana dilakukan oleh seorang yang dipertanggung jawabkan, dapat disyaratkan kepada si pembuatnya (Si Pelaku) .

Kejahatan atau tindak pidana adalah "Menunjukkan kepada dilarangnyaperbuatan". Apakab orang yang melakukan perbuatan itu kemudian juga dipidana ,tergantung pada soal, apakah - dia dalam melakukan perbuatan itu mempunyaikesalahan atau tidak . Berdasarkan pendapat diatas dapat dikatakan bahwa yang dimaksud dengan kejahatan atau tindak pidana adalah Suatu perbuatan manusia bertentangan dengan hukum atau dilarang oleh ketentuan hukum pidana dan terhadap siapa saja yang melakukannya dapat diancam dengan hukuman pidana jika pelakunya mempunyai kesalahan atau dapat dipertanggungjawabkan perbuatannya.
Jelaslah bahwa kekerasan atau kejahatan dalam rumah tangga merupakan suatu perbuatan manusia yang bertentangan dengan hukum atau dilarang oleh ketentuan hukum pidana yang terjadi didalam sebuah komunitas terkecil yang ada dalam masyarakat, yang terdiri dari orang tua dan anak-anak, di mana kepala keluarga berkewajiban memberikan dan mencukupi kebutuhan kasih sayang, pangan, sandang, pendidikan dan lain-lainnya kepada keluarga.

$$
\text { Landasan hukum penanganan }
$$

kekerasan dalam rurnah tangga antara lain adalah pasal 294 ayat (I) Kitab Undang-Undang Hukum Pidana (KUHP) yang mengancam seseorang yang melakukan perbuatan cabul dengan anak.nya yang belum dewasa, anak tiri atau pungutnya, anak peliharaannya dan seterusnya denganancaman pidana Selamalama tujuh tahun. Pasal 340 KUHP tentang pembunuhan berencana, Pasal 341 dan 342 tentang pembunuhan ibu terhadap bayinya, Pasal 356 tentang penganiayaan dalam keluarga dan sebagainya. Selain itu dalam Kitab Undang-Undang Hukum Pidana (KUHP), ada pula undang-undang yang mengatur tentang Penghapusan Kekerasan DalamRumah Tangga.

\section{B. Jenis dan Bentuk Kekerasan Suami-lstri Dalam Rumah Tangga}

Jenis dan bentuk-bentuk kekerasan dalam rumah tangga yang terjadi antara suami istri dalam perkawinannya di Kabupaten Pidie. Berdasarkan penelitian dilapangan ditemukan bahwa setiap informasi istri maupun suami dalam penelitian ini sebagai besar pernah mengalami kekerasan dalam rumah tangganya, namun korban kekerasan paling banyak dialami oleh para istri, Kekerasan yang dialami adalah kekerasan seksual, kekerasan fisik, kekerasan psikologis, dan kekerasan ekonomi.

\section{Kekerasan Seksual}

Kekerasan Seksual adalah perilaku dari suami/istri berupa paksaanuntuk mendapatkan pelayanan seksual tanpa kerelaan darisalah satu pasangan, seperti memaksa melakukan hubungan seksual, memaksa selera seksual sendiri, dan tidak memperhatikan kepuasan suami maupunistri. Seks merupak:an salah satu keburuhan dasar manusia dari sebuah perkawinan .

Seks menjadi sarana untuk memperoleh keturunan, kenikmatan seksual dan kepuasan seksual. "Kepuasan seksual merupakan salah 
satu faktor penentu dalam kehidupan keluarga ". Namun bila seorang dari dua insan yang sedang melakukan hubungan seksual tidak menikmatinya, maka hubungan seksual dapat merupakan sesuatu yang ingin dihindari, bahkan dibenci.

Banyak pasangan suami istri yang tidak menikmati hubungan intim yangmereka lakukan. Seks bagi mereka dapat menjadi beban, bahkan dapat dipandang sebagai sesuatu yang harus dihindari. Hal ini terjadi karena salah satu merasa tidak diperlakukan selayaknya. Satu pihak memaksakan kehendak seksualnya tanpa memperhatikan keinginan pihak lain.

\section{Kekerasan Flsik}

Kekerasan Fisik adalah tindakan pemukulan dan serangan fisik yang dilakukan suami/istri terhadap salah satu pasangan yang menyebabkan cedera, Iuka atau cacat, dan juga kematian seperti memukul/menampar, meludahi, menjambak, menendang, menyundut dengan rokok, memukuVmelukai dengan barang/senjata dan me!empar sesuatu.

Karakter istri yang pemarah dan terbiasa melampiaskan kemarahannya, makapada situasi dan kondisi yang memungkinkan terjadinya konflik mereka akan meiakukan kekerasan. Bahwa motivasi yang melatar belakangi mengapa seseorang melakukan kekerasan yaitu karena Compensatory Violence (kekerasan kompentasi), yaitu kekerasan yang terjadi pada orang yang bersikap kasar terhadap suaminya, yang sebenarnya tindakan tersebut dilakukan untuk menutupi kelemahankelemahanyang ada pada dirinya Hal ini juga dipertegas oleh teori agresi yang menyatakan bahwa perilaku agresi manusia adalah karena faktor lingkungan, bukan faktor bawaan.

3.Kekerasao Emosional/Psikologis.

Kekerasan emosional/psikologis dalam penelirian ini adalah tindakan pelecehan yang dilakukan suami/istri terhadap salah satu pasangan berupa ucapan/perkataan yang tidak senonoh, seperti berbicara kasar, mencela dan menghina dan melarang berhubungan dengan keluarga atau teman.

Kekerasan psikologis yang dialami dalam rumah tangga adalah dalam bentuk berbicara kasar, mencaci maki, mencela/menghina dan melarang berhubungan dengan keluarga.Kekerasan psikologis yang dialami korban baik suami maupun istri tidak meninggalkan bekas seperti kekerasan fisik, tetapi kekerasan psikologis dapat meruntuhkan harga diri bahkan memicu dendam di hati.

\section{Kekerasan Ekonomi}

Kekerasan ekonomi dalam rumah tangga adalah perampasan hak dan kewajiban yang dilakukan suami maupun terhadap istri terhadap salah satu pasangan dalam kebebasan mengatur ekonorni keluarga, Pengertian ini menunjukkau bahwa keadaan istri yang bekerja dimamfaatkan oleh suami untuk melakukankekerasan ekonomi terbadap istrinya. Sebagian 'suami tidak mau memberi gajinya karena mereka tahu bahwa istrinya berpenghasilan sehingga dapat menopang ekonomi keluarga. Para suami sangat yakin bahwa istri ini akan menggunakan gajinya karena mereka tidak akan membiarkan anaknya kelaparan sendiri.

\section{Kekerasan Berganda/Berlapis}

Berdasarkan kasus-kasus (jenis dan bentuk) kekerasan dalam rumah tangga, dimana suami istri sebagai korban, dalam penelitian ini ditemukan juga kasus kekerasan berganda/berlapis dimana suami maupun istri mengalami lebih dari satu jenis dan bentuk kekerasan dalam rumah tangganya.

Kasus-kasus kekerasan domestik yang ditemukan dalam penelitian secara umum merefleksikan suatu bentuk ketidakdilan gender, atau suatu konsekwensi dari adanya relasi yang timpang antara perempuan dan lakilaki sebagai bentukan nilai dan norma sosial.

\section{C.Faktor-Faktor Yang Menycbabakan}

Kekerasan Suami-Istri Dalam RumahTangga. Di dalam rumah tangga, ketegangan maupun konflik merupakan hal yang biasa. Perselisihan pendapat, perbedaan, pertengkaran, saling mengejek, atau bahkan memaki bahkan halyangumum terjadi. Tapi semua itu, pada era globalisasi dapat menjadi bagian dari bentuk kekerasan dalam rumahtangga yang berbasis gender, yang secara spesifik mengacu kepada pengertian kekerasan terhadap perempuan yang ada dalamDeklarasi Penghapusan Kekerasan Terhadap Perempuan . Analisis terhadap faktor-faktor penyebab kasus kekerasan seksual, fisik, psikologis dan ekonomi terhadap informan, penelitianini menunjukkan adanya enam faktor penyebab kekerasan, yaitu pertama, kondisi kepribadian dan psikologis istri dansuami yang tidak stabil. Kedua, kemandirian ekonomi istri. Ketiga, masalah anak.Keempat, cemburu. Kelima, 
masalah anak. Keenam, campur tangan orang ketiga.

1. Kondisi Kepribadian dan Psikologi

Suami-Istri Yang Tidak Stabil

Kondisi kepribadian danpsikologi suamiistri yang tidak stabil dapat mengakibatkan terjadinya kekerasan dalam rumah tangga. Bahwa kekerasan suami maupun istri terbadap salah satu pasangaunya dalam rumah tangga dikarenakan "kekerasan dilakukan sebagai sumber daya untuk menyelesaikan masalah" (polakebiasaan turunan dari keluarga atau orang tua).

Dalam penelitian ini ditemukan bahwa suami maupun istri yang melakukan kekerasan fisik, emosional dan ekonomi kepada salah satu pasangannya dalarn rumah tangga, disebabkan karena faktor internal seperti karakter yang emosional, keras kepala, pencemburu dantersinggung. Jenis-jenis kekerasan yang dilakukan suami maupun istri terhadap salah satu pasangannya dalam rumah tangga akibat dari kondisi kepribadian dan psikologis lidak stabil adalah kekerasan fisik, emosional dan ekonomi.

\section{Kemandirian Ekonomi Istri}

Kekerasan terbadap perempuan dalam rumah tangga (KDRT) biasa disebabkan oleh ketergantungan ekonomi istri kepada suaminya, karena mungkin istri akan direndahkan oleh suami bahwa salah satu faktor yang dapat menyebabkan seorang suami melakukan kekerasan terhadap istrinya adalah ketidak mandirian si istri secaraekonomi . Kemudian teori bahwa kemandirian ekonomi yang dimiliki oleh seorangperempuan akan meningkatkan harga dirinya dan menyebabkannya memiliki posisitawar yang tinggi dalam hubungan dengan suaminya

1. Perselingkuhan

Perselingkuhan suami dengan perempuan lain menjadi salah satu penyebab terjadinya kekerasan dalam rumah tangga. Perselingkuhan adalah kekerasan suami yang terjadi seeara tiba-tiba, tanpa atau diketahui oleh istri.

istri. Perselingkuhan dapat menyebabkan istri mengalami kekerasan seksual, fisik, psikologis dan ekonomi dalam rumah tangganya .

\section{Masalah Anak}

Masalah anak merupakan faktor lain yang menyebabkan timbulnya kekerasan domestik. Jenis-jenis kekerasan yang dilakukan suami maupun istri yang sering dilakukan pasangannya dalam perkawinan akibat masalah anak adalah.. kekerasan fisik dan emosional.

\section{Cemburu}

Salah satu terjadinya kekerasan suami terhadap istri adalah faktor cemburu. Sifat manusia yang mendasar yang sering dilibat sebagai karakteristik paling merusak dalarn perilaku manusia dalam perilaku manusia, Hal ini sering terlibat pada pria danwanita.

\section{Campur Tangan Pihak Ketiga}

Campur tangan anggota dari pihak istri terutama ibu mertua, salah satu penyebab timbulnya kekerasan antara suami-istri.ibu mertua yang suka menjelek-jelekkan menantunya dapat menyebabkan pemicu konflik dalam rumah tangga. Bentuk-bentuk kekerasan yang timbul akibat campur tangan pihak keluarga antara lain kekerasan fisik dan psikologis.

\section{PERLINDUNGAN IIUKUM TERIIADAP KORBAN KEKERASAN DALAM RUMAH TANGGA DI WILAYAH HUKUM POLRES PIDIE}

\section{A. Perlindungan Hukum Terhadap Korban Kekerasan Dalam Rumah Tangga.}

Perlindungan hukumadalah setiap usaha yang dilakukan oleh pihak-pihak untuk menggulangi kekerasan terhadap perempuan, kekerasan dalam bentuk fisik, psikologis, seksual dan kekerasan ekonomi. Pihak-pihak yang dapat melakukan perlindungan hukum bagi perempuan korban kekerasan dalam rumah tangga, bisa siapa saja misalnya dapat dilakukan oleh keluarga korban, tentangga korban, tokoh masyarakat, aparat penegak hukum (polisi, jaksa, hakim), lembaga sosial dan lainsebagainya .

Yang jelas pihak-pihak dimaksud dapat memberikan rasa aman terhadap istri korban kekerasan suami. Perempuan korban kekerasan dalam rumah tangga sering tidak dapat berbuat banyak atau dalam keadaan binggung, karena tidak tahu harus menggadu kemana, ke rumah asal belum tentu diterima. Hal ini disebabkan oleh adanya budaya di mana perempuan yang sudah kawin menjadi tanggung jawabsuaminya. Perlindungan dan pelayanan yang diberikan oleh institusi dan lembaga sesuai tugas dan fungsinya masingmasing:

Perlindungan oleh kepolisian berupa perlindungan sementara yang diberikanpaling lama 7 (tujub) hari, dan dalam waktu I $\mathrm{x}$ 
24 jam sejak memberikanperlindungan, kepolisian wajib meminta surat penetapan perintah perlindungan daripengadilan. Perlindungan sementara oleh kepolisian ini dapat dilakukan bekerjasama dengan tenaga kesehatan, pekerja sosial, relawan pendamping dan pembimbing rohani untuk mendampingi korban.

Sejalan dengan itu, sesuai tugas dan kewenangannya kepolisian dapatmelakukan penyelidikan, penangkapan dan penahanan dengan bukti permulaan yang cukup disertai dengan surat perintah penahanan terhadap pelaku kekerasan dalam rumah tangga. Bahkan kepolisian dapat melakukan penangkapan dan penahanan tanpa surat perintah terhadap pelanggaran perintah perlindungan, artinya surat penangkapan dan penahanan itu dapat diberikan setelah 1 x 24 jam .

Perlindungan oleb Advokat diberikan dalam bentuk Kosultasi Hukum,melakukan mediasi dan negosiasi diantara pihak termasuk keluarga korban ditngkat penyidikan, penuntutan, dan pemeriksaan dalam sidang pengadilan (litigasi), melakukan koordinasi dengan sesama penegak bukum, relawan pendamping, dan pekerja sosial (kerjasama dan kemitraan),

Perlindungan dengan Penetapan Pengadilan dikeluarkan dalam bentuk perintah perlindungan yang diberikan selama I (satu) tahun dan dapat diperpanjang. Pengadilan dapat melakukan penahanan dengan surat perintah penahanan terhadap pelaku kekerasan dalam rnmah tangga (KDR1) selama 30 (tiga puluh) hari apabila pelaku tersebut melakukan pelanggaran atas surat pernyataan yang ditandatanganinya mengenai kesanggupan untuk mematuhi perintahperlindungan dari pengadilan.Pengadilan juga dapat memberikan perlindungan tambahan alas bahaya yang rnungkin timbul terhadap korban.Pelayanan Tenaga Kesehatan penting sekali artinya terutama dalam upayapemberian sanksi terhadap pelaku kekerasan dalarn rumah taogga. Tenaga kesehatao sesuai profesinya wajib memberikan laporan tertulis basil pemeriksaan medis dan membuat visum et repertum atas pennintaan penyidlk kepolisian atau membuat surat keterangan medis Iainnya yang mempunyai kekuatan hukum sebagai alat bukti .

Pelayanan oleh pembimbing rohani yang diberikan untuk memberikan penjelasan mengenai hak, kewajiban dan memberikan penguatan iman dan taqwa kepada korban. Bentuk perlindungan dan pelayanan ini masih bersifat normativebelum inflementatif dan teknis operasional yang mudah dipahami, dan mampudijalankan dan mudah diakses oleh korban kekerasan dalam rumah tangga.

Adapun tugas pemerintah untuk merumuskan kembali pola dan strategi pelaksanaan perlindungan dan pelayanan dan mensosialisasikan kebijakan itu dilapangan. Tanpa upaya sungguh-sungguh dari pemerintah dan semua pihak, maka akan sangat sulit dan mustahil dapat mencegah apalagi menghapus tindak kekerasan dalam rumah tangga dimuka bumi Indonesia ini, karena berbagai faktor pemicuterjadinya kekerasan dalam rumah tangga di negeri ini amatlah subur .

Bahwa anggapan orang terjadinya kekerasan dalam rumah tangga, merupakan akibat dari suatu sebab konvensional seperti disharmonisasi dari tekanan sosial ekonomi yang rendah, perangai dan tabiat pelaku yang kasar, serta gagal dalam karier dan pekerjaan ternyata tidaklah sepenuhnya benar, karena kekerasan dalam rumah tangga justru acapkali dilakukan oleh mereka yang kondisi sosial ekonominya baik,sukses karir dan pekrjaannya, bahwa berpendidikan tinggi .

Sebelum keluarnya UU Nomor 23 Tahun 2004 tentang Perlindungan Hukum Terhadap Perempuan Korban Kekerasan Suami diatur dalarn Pasal 356 ayat (I) KUHP, Pasal1365 KUHP perdata, Pasal 24 UU No I Tahun 1974 tentang Perkawinan, Pasal I UU No. 7 Tahun 1984 tentang Pengesahan Konvensi Penghapusan Segala Bentuk Deskriminasi Terhadap Wanita/Perempuan, Pasal 17 UU No 39 Tahun 1999 tentang Hak Asasi Manusia (HAM). Setelah berlakunya UU No. 23 Tahun 2004 tentang Penghapusan Kekerasan Dalam Rurnah Tangga, pelaku kekerasan dalam rumahtangga diatur dalam Bab ll, Pasal 5, Pasal 6, Pasal 7, Pasal 8 dan Pasal 9 UU No 23Tahun 2004. Ketentuan pidananya diatur pada Pasal 44, Pasal 45, Pasal 46, Pasal 47, Pasal 48, Pasal 48, Pasal 49 dan 50.

\section{B. Hambatan Yang Di Hadapi Oleh Penyidik Polres Pidie Dalam Pengungkapan dan Penanganan Tindak KekerasanDalam rumah Tangga.}

Berdasarkan hasil penelitian dapat diketahui bahwa setidaknya ada dua hambatan yang dihadapi penyidik dalam pengunkapan dan penanganan kejahatan dalam 
keluarga dalam wilayah hukum Polres Pidie. Hambatan tersebut antara lain adalah masih adanya warga masyarakat yang tidak melaporkan kejahatan yang terjadi dalam keluarganya, dan adanya cara pandang yang keliru tentang makna kekerasan dalam rumah tangga. Semua itu menyebabkan penanganan kekerasan dalam rumah tangga menjadi tidak dapat dilakukan secara optimal.Pada uraian di bawah ini ditemukan masing-masing bentuk hambatantersebut, yaitu sebagai berikut :

1. Masih Adanya Warga Masyarakat Yang Tidak Melaporkan Kejahatan YangTerjadi Dalam Rumah Tangga.

Penanganan tindak pidana kekerasan dalam rumah tangga di wilayah hukum Polres Pidie terkendala adanya sikap sementara warga masyarakat yang enggan melapor tentang kejahatan yang terjadi dalam keluarganya kepada aparat Polri terdekat sehingga pelaku kejahatan merasa leluasa dalam menjalankan aksinya. Dalam Praktek, masih ada masyarakat yang memilih diam atau enggan melaporkan kepada pihak yang berwajib apabila menjadi korban kejahatan dalam keluarga. Walaupun kejadian itu tidak dapat diterima dan menyebabkan gangguan psikologisyang amat berat bahkan mengancam keselamatan jiwa mereka sekeluarga, akan tetapi mereka bersikap seolah-olah tidak terjadi sesuatu dalam keluarga mereka .

Ada berbagai pertimbangan yang menyebabkan masyarakat tidak melaporatas tindak pidana kekerasan dalam rumah tangga tersebut. Pertimbangan utama adalah demi menjaga keutuhan rumah tangga yang akan terancam jika ada yang berinisiatif untuk melaporkan tindak pidana yang akan terjadi itu kepada aparat Polri. Korban hanya berharap tidak akan terjadi lagi tindak pidana seperti itu dan menganggapnya sebagai suatu musibab dalam keluarga yang tidak perlu diketahui atau dicampuri oleh orang lain termasuk penegak hukum sekalipun . Pertimbangan lainnya adalah adanya perasaan malu dan menjaga martabat keluarga. Perasaan malu akan timbul jika kejahatan yang terjadi dalam keluarga itu menjadi urusan polisi dan dengan demikian akan ada anggota keluarga yang ditangkap dan ditahan oleh polisi.

Apabila itu, terjadi maka ada anggapan bahwa hal itu sama dengan mempermalukan diri sendiri di depan umum. Oleh karena itu agar tidak terjadi kerugian yang kedua kalinya terutama kerugian moral, maka ada diantara warga masyarakat yang akhimya memilih tidak mengadukan peristiwa kejahatan dalamrumahkeluarga itu kepada polisi .

2. Adanya Pandangan Yang Keliru Tentang Makna Kekerasan Dalam RumabTangga

Salah satu faktor yang menghambat upaya polri dalam upaya penangganan kejahatan yang terjadi dilingkungan keluarga adalah adanya persepsi yang keliru tentang makna kejahatan .dalam keluarga dari sebagian masyarakat di wilayah hukum Polres Pidie. Persepsi yang keliru tersebut antara lain adalah dalam bentuk bahwa berbagai perbuatan yang dapat dikatagorikan sebagai kejahatan keluarga hanya dianggap sebagai masalah internal dalam keluarga sehingga tidak perlu dilaporkan kepada pihak yang berwenang untuk diselesaikan sesuai denganketentuan hukum yang berlaku .

Demikian pula tindakan pemukulan atau penganiayaan yang terjadi dalamkeluarga misalnya seorang bapak memukul atau menganiaya isteri dan anak-anaknya sendiri berkali-kali den telah menganggu kesehatan si isteri dan anak-anaknya. Tindakan seperti ini ada yang masih dianggap sebagai tindakan yang bersifat internaldalam keluarga sebagai proses penegakan disiplin oleh kepala keluarga terhadapkeluarganya .

Tindakan penganiayaan yang, terjadi dalam keluarga apalagi sampai mengakibatkan Iuka sebenamya telah termasuk dalam pengertian dalam kekerasan dalam rumah tangga, yaitu setiap perbuatan terhadap seseorang terutama perempuan, yang berakibat timbulnya kesengsaraan atau penderitaan secara 'fisik, seksual, psikologis, dan atau penelantaran rumah tangga termasuk ancaman untuk melakukan perbuatan, pemaksaan atau perampasan kemerdekaan secara melawan hukum dalam lingkup rumah tangga.

Adanya kenyataan sebagaimana dikemukakan di alas menyebabkan upaya penanganan kejahatan dalam keluarga tersebut mengalamihambatan sendiri, karena belum optimalnya bantuan informasi dari masyarakar - Hal ini disebabkan oleh masih adanya pola pikir yang menganggap kejahatan yang terjadi dalam keluarga tersebut masih merupakan masalah internal keluarga, sehingga tidak perlu orang luar ikut mencampuri masalah yang seperti ini. 


\section{Upaya Pemerintah Dalam Melindungi Korban Kekerasan Dalam RumahTanggaDalam Kasus Penganiayaan.}

Untuk mencegah menghentikan kekerasan pada anak dan perempuan dibutuhkan beberapa pendekatan diantaranya, pendekatan individu, yaitu dengan cara menambah pemahaman agama, karena tentunya seorangyang rnempunyai pemahaman agama yang kuat (terutama islam) akan lebih tegar menghadapi situasi- situasi yang menjadi factor terjadinya kekerasan, Terlebih Islam menganjarkan aturan hidup dalam berumah tangga, baik sikap kepada istri atau kepada anak dan juga mengajarkan interaksi sosial yang baik. Islam sangat mengutuk segala bentuk kekerasan.Islam memperbolehkan bercerai jika ada kekerasan dalam rumah tanggasebagai mana hadist dari Aisyah RA berkata, bahwasaya Habibah binti Sahl, istri Tsabit bin Qais dipukul suaminya sampai memar. Keesokan paginya Habibah melaporkan tindakan kekerasan suaminya kepada Rasulullah SAW. Kemudian Rasulullah memanggil Tsabit. Sabdanya, "Ambillah sebagian hartanya (maharoya) dan ceraikania!" Tsabit bertanya, "Apakah hal itu sebagai penyelesaiannya ya Rasulullah, "Ya betul." Tsabit berkata lagi, "Sesungguhnya saya sudah memberinya dua kali lipat, dan keduanya berada di tangannya. "Kata Rasulullab lagi, "Ambillahkedua bagian tersebut, dan ceraikan ia!" Lalu Tsabit pun melaksanakan perintahtersebut. ( HR. Imam Abu Dawud ).

Upaya pemerintah dalam penghapusan kekerasan dalam rurnah tangga diantaranyamerumuskan kebijakan kasus kekerasan dalam rumah tangga dan menyelenggarakanberbagai aturan penghapusan kekerasan dalam rumah tangga yang berlaku dalam rumah tangga yang berhak diketahui oleh setiap warga yang telah berumah tangga .

Upaya pemerintah dan pemerintah daerah menyediakan fasilitas bagi korban kekerasan dalam rumah tangga (KDRT), baik itu berupa pelayanan khusus atau perlindungan terhadap korban. Pemerintah danpemerintah daerah bekerjasama dengan masyarakat ataupun instansi-instansi sosial dalam penanganan kasus kekerasan dalam rumah tangga ini. Pihak terkait selain pemerintah yang menolong korban kekerasan dalam rumah tangga wajib menolong sesuai dengan batas kemampuannya Komisi Nasional Anti Kekerasan terhadap Perempuan, atau Komnas Perempuan, mengemban mandat untuk menciptakan kondisi yang kondusif untuk penghapusan kekerasan yang meluas dan sistematik. Mandat ini dijalankan melalui advokasi untuk pembaruan hukum dan kebijakan; peningkatan pemahaman masyarakat tentang kekerasan terhadap perempuan-penguatan kapasitas lembaga- lembaga pemerintah maupun masyarakat yang bekerja untuk dan dengan perempuan korban kekerasan terhadap perempuan dan penanganannya.

Komnas Perempuan mengacu pada istrumen hakasasimanusia (HAM)internasional dan hukum nasional dalam menjabarkanmakna kekerasan terhadapperempuan. Pada tahun 1993 di Jenewa, komunitas intemasional termasuk Indonesiamemberi pengakuan bahwa kekerasan terhadap perempuan adalah pelanggaran Hak Asasi Manusia (HAM), Kekerasan dalam rumah tangga (KDRT) merupakan salah satu bentuk kekerasan yang dialami perempuan secara terus menerus sehingga korban sering terkondisikan untuk menerimanya sebagai suatu kewajaran yang menyakitkan.

Data ini kemudian dikemas dalam bentuk laporan yang dapat diakses oleh masyarakat dan pemerintah untuk kepentingan yang berdampak pada upaya penghapusan kekerasan dalam rumah tangga.Dalam menjalankan program-program di atas, Komnas Perempuan bekerjasama dengan mitra-mitra dari pemerintah dan lembanga Negara lainnya, serta organisasi masyarakat yang fokus pada isu hak asasi manusia (HAM) dan kekerasan terhadap perempuan.

Untuk menemukan kasus-kasus kekerasan dalam rumah tangga maka masyarakat perlu digalakkan peodidikan mengenai Hak asasi manusia (HAM) dan pemberdayaan perempuan; menyebarkan informasi dan mempromosikan prinsip hidup sehat, anti kekerasan terhadap perempuan dan anak serta menolak kekerasan sebagai cara untuk memecahkan masalah;mengadakan penyuluhan untuk mencegah kekerasan mempromosikan kesetaraan jender, mempromosikan sikap tidakmenyalahkan korban melalui media .Sedangkan untuk pelaku dan korban kekerasansendiri, sebaiknya mencari bantuan pada Psikolog untuk memulibkan 
kondisi psikologisnya. Bagi suami sebagai pelaku, bantuan oleh Psikolog diperlukan agar akar permasalahan yang menyebabkannya melakukan kekerasan dapat terkuak dan belajar untuk berempati dengan menjalani terapi kognitif. Karena tanpa adanoya perubaban pola pikir suami dalam menerima dirinya sendiri dan istrinya maka kekerasan akan kembali terjadi.

Sedangkan bagi istri yang mengalami kekerasan perlu menjalani terapi kognitif dan belajar untuk berperilaku asersif. Selain itu, istri juga dapat meminta bantuan pada Lembaga Swadaya Masyarakat (LSM) yang menangani kasus-kasus kekerasan pada perempuan agar mandapat perlindungan. Suami dan istri juga perlu. untuk terlibat dalam empati kelompok dimana masingmasing dapat melakuk:an sharing sehingga membutuhkan keyakinan bahwa hubungan perkawinan yang sehat bukan dilandasi oleh kekerasan namun dilandasi oleh rasa saling simpati. Selain itu, suami dan istri perlu belajar bagaimana bersikap asertif dan memanage emosi sehingga jika ada perbedaan pendapat tidak perlu menggunakan kekerasan karenaberpotensi anak akan mengimitasi perilaku kekerasan tersebut .

Oleh karena itu, anak perlu diajarkan bagaimana bersikap empati dan memanage emosi sedini mungkin namun semua itu harus diawali dari orangtua. Menggalami kekerasan dalam rumah tangga membawa akibat-akibat negatif yang berkemungkinan mempengaruhi perkembangan korban di masa mendatang dengan banyak cara. Dengan demikian, perhatian utama harus diarahkan pada pengembangan berbagai strategi untuk mencegah terjadi penganiayaan dan merninirnalkan efeknya yang merugikan ada beberapa solusi untuk mencegah kekerasan dalam rumah tangga antara lain:

1. Membangun kesadaran bahwa persoalan kekerasan dalam rumah tanggaadalah persoalan sosial bukan individual dan merupakan pelanggaran hukumyang terkait dengan Hak Asasi.Manusia (HAM).

2. Sosialiasasi pada masyarakat tentang kekerasan dalam rumah tangga adalah tindakan yang tidak dapat dibenarkan dan dapat diberikan sangsi hukum. Dengan cara mengubah pondasi kekerasan dalam rumah tangga di tingkat masyarakat pertama-tama dan terutama membutuhkan.

3. Adanya konsensus bahwa kekerasan adalah tindakan yang tidak dapatditerima.

4. Mengkampanyekan penentangan terhadap penayangan kekerasan di media yang mengesankan kekerasan sebagai perbuatan biasa, menghibur dan patut menerima penghargaan .

5. Peranan Media Massa, media cetak, televisi, bioskop, radio dan internetadalah macrosystem yang sangat berpeogaruh untuk dapat mencegah dan mengurangi kekerasan dalarn rumah tangga , bagaimana media massa dapat memberikan suatu berita yang bisa merubah suatu pola budaya kekerasan dalam rumah tangga adalah suatu tindakan yang dapat melanggar hukum yang dapat di kenakan hukuman penjara sekecil apapun bentuk dari penganiayaan.

6. Mendampingi korban dalam penyelesaian persoalan (konseling) serta kemungkinan menempatkan dalam shelter (tempat penampungan) sehinggapara korban akan lebih terpantau dan terlindungi serta konselor dapat dengan cepat membantu pemulihan secara psikis.

Budaya masyarakat yang "mengbendaki" agar istri bisamenyembunyikan atau merahasiakan persoalan keluarganya pada orang lain, agar tidak menjadi aib keluarga. Sebaliknya orang lain pun tidak pantas kalau ikut campur dalam persoalan rumah tangga orang lain. Idealnya memang masalah keluarga sebaiknya diselesaikan oleh -keluarga sendiri, namun jika tidak berhasil, maka masalah kekerasan dalamrumah tangga akan menjadi masalah yang luas dan akut. Tidak semua kekerasan dalam rumah tangga dikatagorikan sebagai delik aduan, artinya korban (termasuk orang tua yang diberi kuasa) saja yang bisa melaporkan kejadian ini kepada yang berwajib. Akan tetapi anggota masyarakat yang mengetahui terjadinya kekerasan dalam rum.ah tangga diwajibkan untuk sebisa mungkin memberikan perlindungan kepada korban dengan carat melalui prosedur tertentu.

Untuk merealisasikan penghapusan kekerasan dalam rumah tangga mencegahterjadinya kekerasan dalam rumah tangga, menindak pelaku kekerasan dalarn 
rumah tangga dan melindungi korban kekerasan dalam rumah tangga, Pasal I UU No. 23Tahun 2004 harus dilakukan usaha terpadu, saling bersinergi antara pemerintah danmasyarakat agar keberhasilan penghapusan kekerasan dalarn rumah tangga cepatterwujud .

Pemerintah bertanggung jawab dalam upaya pencegahan kekerasan dalam rumah tangga. Dalam rangka melaksanakan tanggnng jawab tersebut, pemerintanantara lain wajib untuk :
a. Merumuskan kebijakan tentang Penghapusan kekerasan dalarn rumah tangga.
b. Menyelenggarakan komunikasi, informasi dan edukasi tentang kekerasandalam rumah tangga.
c. Menyelenggarakan sosialisasi dan advokasi tentang kekerasan dalam rumahtangga Pasal 11 ayat (I) Undang- undang No. 23 tahun 2004).

Dalam rangka untuk penyelenggaraan pelayanan terhadap korban kekerasan dalam rumah tangga pemerintah dan pemerintah daerah sesuai dengan fungsi dan tugas masing-masing dapat melakukan upaya :

$>$ Penyediaan ruang pelayanan khusus (RPK) di kantor kepolisian .

$>$ Penyediean aparat, tenaga kesehatan, pekerja sosial, dan pembimbing rohani.

$>$ Pembuatan danpengembangan sistem dan mekanisme kerja sama programpelayanan yang melibatkan pihak yang mudah diakses oleh korban.
$>$ Memberikan perlindungan bagi pendamping, saksi, keluarga dan temankorban."

Dalam upaya mencegah kekerasan dalam rumah tangga dan memberikan perlindungan memberikan rasa amau kepada korbau kekerasan dalarn rumah tangga, auggota masyarakat juga diharapkau peduli terhadap peristiwa kekerasan dalam rumahtangga, sehingga setiap orang yang mendengar, melihat atau mengetahui terjadinya peristiwa kekerasan dalam rumah tangga wajib melakukan upaya-upaya sesuai dengan batas kemampuannya untuk.
$>$ Mencegah berlangsungnya tindak pidana

$>$ Memberikan perlindungan kepada korban

$>$ Memberikan pertolongan darurat

$>$ Membantu proses permohonan penetapan perlindungan.

\section{PENUTUP}

\section{Kesimpulan}

Berdasarkan hasil penelitian dan pembahasan maka dapat dikemukakan beberapa kesimpulan dan saran, yaitu sebagai berikut.Analisis mengenai kekerasan dalam rumah tangga di Wilayah Hukum Polres Pidieadalah sebagai berikut :

1. Kekerasan dalam rumah tangga adalah perbuatan seseorang atau kelompok orangmenyebabkan cedera atau matinya orang atau menyebabkan kerusakan fisik ataubarang, yang terjadi dilingkungan sebuah rumah atau keluarga. Jenis dan bentuk kekerasan suami istri dalam rumah tangga yaitu kekerasan seksual, kekerasan fisik, kekerasan emosional/psikologis, kekerasan ekonomi, kekerasan berganda/berlapis, Adapun faktor-faktor penyebab terjadinya tindak kekerasan dalam rumah tangga antara lain: kondisi kepribadian dan psikologis suami-istri yang tidak stabil, kemandirian ekonorni istri, perselingkuhan, masalah anak, cemburu, campur tangan orang ketiga.

2. Ada dua hambatan yang dihadapi Polri dalam penanganan kejahatan dalam keluarga di wilayah 'hukum Polres Pidie. Hambatan tersebut antara lain adalah masih adanya warga masyarakat yang tidak melaporkan kejahatan yang terjadi dalam keluarganya, dan adanya cara pandang yang keliru tentang maknakekerasan dalam rumah tangga. Semua itu menyebabkan penanganan kekerasan dalam rumah tangga menjadi tidak dapat dilakukan secara optimal.

3. Upaya pemerintah dalam melindungi korban kekerasan dalam rumah tangga antara lain lebih mensosialisasi pemahaman mengenai makna perkawinan sesuai dengan agama yang dianut dan UU KDRT perlu disosialisasikan oleh lembaga penasehat perkawinan (KUA) melalui konseling kepada calon pasangan suami 
istri sebelum memasuki perkawinan agar mengetahui tentang hak dan kewajibannya masing-masingsehingga dapat mewujudkan keluarga yangsakinah, mawaddah dan warahmah.

\section{Saran}

1. Disarankan kepada suami istri perlu ditanamkan prinsip "kemitrasejajaran dan keadilan" gender, dimana suami maupun istri sama-sama memiliki hak, kewajiban, peranan dan kesempatan yang dilandasi oleh keterbukaan, pengertian, menghormati, menghargai, kerjasama dan musyawarah dalam memutuskansesuatu bagi keutuban dan kelangsungan nunah tangga.

2. Disarankan kepada aparat Polres Pidie untuk lebih meningkatkan lagi operasi pemberantasan penyakit masyarakat, seperti tindak pidanaperjudian, peredaran berbagai jenis minuman keras dan narkotika di daerah ini. Hal ini dikarenakan barang-barang terlarang tersebut sering terjadi faktor pencetus untuk terjadinya berbagai tindak pidana kekerasan dalam rumah tangga, baik dalam bentuk perselingkuhan, kejahatan seksual dalam keluarga, penganiayaan, pencurian dan sebagainya.

3. Disarankan kepada para alim ulama dan pemuka masyarakat di wilayah hukum Polres Pidie, untuk apa meningkatkan sosialisasi tentang pentingnya kedamaian dan kesejahteraan dalam kehidupan berkeluarga yang berlandaskan kepada ajaran Islam serta menghindari segala perbuatan yang dapat dikatagorikan sebagai tindak pidana kekerasan dalam rumah tangga. Dengan demikian masyarakat akan lebih mengetahui bahwa tindakan-tindakan tertentu yang terjadi dalam kehidupan rumah tangganya dapat digolongkan sebagai tindak pidanakekerasan dalam rumah tangga dan dapat dipidana.

\section{DAFTAR PUSTAKA}

\section{A. Buku-Buku}

AriefBudiman. 1982. Pembagian KerjaSecara Seksual. Gramedia, Jakarta.

C.S.T.Kansil dan Cristine S.T. Kansil, 1995 Latihan Ujian Hukum Pidana, Sinar Grafika, Jakarta
Fromm, Erich. 2000. Akar Kekerasan Analisis Sosio-psikologiatas Watak Manusia. Pustaka Pelajar,Jogjakarta.

Gelles, R,J. 1995. Violence in the Family.-A review of research in the Seventies.

Journal Of Marriage and the Family, 42 (4).

Hasan Ali dan Kawan-kawan, 2005, Kamus Besar Bahasa Indonesia, edisiketiga, Balai pustaka, Jakarta.

Handayani, Trisakti, sugiarti. 2002. Konsep dan teklmik Penelutan Gender. MM Press, Malang.

Moors, A. 1995.Woman, Property, and is/am.Cambridge Univercity Press, New York.

Roesalan Saleh, 1988,Perbuatan pidana don Pertanggung jawaban pidana, Dua Pengenian Dasar dolam Hu/mm Pidana; Aksara Barn, Jakarta.

Ritzer, George dan Goonnan, J. Douglas. 2004. Teori Scsiologi Modern. Kencana, Jakarta.

Shanna, A. 1994.Protection to Won!en f.!1 Matrimonial Home. Deep And Deep Publication, New Delhi.

Wirjono Prodjodikoro, 1986. Asas-asas Hukum Pidana di Indonesia, Eresco, Bandung.

\section{B. PeraturanPerundang-uudangan}

Kitab Undang-Undang Hukum Pidana (KUHP)

Undang-Undang Nomor 8 Tahun 1981Tentang Hukum Acara Pidana

Undang-Undang Nomor 23 Tahun 2004

Tentang Pengahapusan Kekerasan

Dalam Rumah Tangga (PKDR1).

Undang -Undang Nomor 1 Tahun 1974 tentang

Perkawinan. 